\title{
Antimutagenic and free radical scavenger effects of leaf extracts from Accacia salicina
}

\author{
Jihed Boubaker ${ }^{1+}$, Hedi Ben Mansour ${ }^{1 \dagger}$, Kamel Ghedira $^{2}$ and Leila Chekir-Ghedira ${ }^{1,2^{*}}$
}

\begin{abstract}
Background: Three extracts were prepared from the leaves of Accacia salicina; ethyl acetate (EA), chloroform (Chl) and petroleum ether (PE) extracts and was designed to examine antimutagenic, antioxidant potenty and oxidative DNA damage protecting activity.

Methods: Antioxidant activity of A. salicina extracts was determined by the ability of each extract to protect against plasmid DNA strand scission induced by hydroxyl radicals. An assay for the ability of these extracts to prevent mutations induced by various oxidants in Salmonella typhimurium TA102 and TA 104 strains was conducted. In addition, nonenzymatic methods were employed to evaluate anti-oxidative effects of tested extracts.

Results: These extracts from leaf parts of A. salicina showed no mutagenicity either with or without the metabolic enzyme preparation (59). The highest protections against methylmethanesulfonate induced mutagenicity were observed with all extracts and especially chloroform extract. This extract exhibited the highest inhibitiory level of the Ames response induced by the indirect mutagen 2- aminoanthracene. All extracts exhibited the highest ability to protect plasmid DNA against hydroxyl radicals induced DNA damages. The ethyl acetate (EA) and chloroform (Chl) extracts showed with high TEAC values radical of 0.95 and $0.81 \mathrm{mM}$ respectively, against the ABTS ${ }^{+}$.
\end{abstract}

Conclusion: The present study revealed the antimutagenic and antioxidant potenty of plant extract from Accacia salicina leaves.

\section{Background}

Exposure to genotoxic chemicals present in food, in the environment, and used in medical treatment can alter the genetic material permanently, and thus may lead cancer [1]. On the other hand, oxidative stress, caused by reactive oxygen species (ROS), is known to cause the oxidation of biomolecules, leading to cellular damage. The tissue injury caused by ROS may include DNA protein and lipids damage [2,3]. Antigenotoxic plant can counter or prevent the adverse effect caused by DNAdamaging chemicals [4]. Drugs obtained from plants have been investigated for the possible presence of mutagenic and/or carcinogenic substances, following the criteria and norms established for synthetic medicines. Fortunately, numerous defense systems protect the cellular macromolecules against oxidation. DNA repair

\footnotetext{
* Correspondence: Leila.chekir@laposte.net

† Contributed equally

'Department of Cellular and Molecular Biology, Faculty of Dental Medicine,

Rue Avicenne,Monastir, 5000, Tunisia

Full list of author information is available at the end of the article
}

systems take charge of the oxidized bases, the basic site, and the single strand breaks generated by oxidative process. However, cell defences against oxidative stress are also known to decrease through changes in gene expression in response to oxidative stress [5]. The detection and evaluation of the cytotoxic, mutagenic and carcinogenic effects of plant compounds are of fundamental importance in order to reduce the possible risks of these damaging effects. There is an increasing interest in the natural antioxidants contained in the medicinal and dietary plants, which are candidates for the prevention of oxidative damages. Antioxidants from dietary and medicinal plant sources, particularly those containing phenolic compounds, have a significant antioxidant activity [6]. Modern pharmaceutical industries largely take profit of the diversity of secondary metabolites from vegetables for new drug research. This is the case of Accacia salicina, The genus Acacia is frequently used for the treatment of various illnesses because of their reputed pharmacological effects; published information indicates that Acacia has hypoglycemic effects [7],

\section{Ciomed Central}


antibacterial, [8] anti-inflammatory activity [9], cestocial [10], spasmogenic and vasoconstrictor activities [11], antihypertensive and antispasmodic activities [12], antiagregation platelet effect [13], as well as an inhibitory effect against hepatitis $C$ virus [14]. The present study was designed to examine antimutagen, antioxidant potenty and oxidative DNA damage protecting activity of plant extract from Accacia salicina leaves in relation to their total polyphenol, tannin, sterol and flavonoid content.

\section{Methods}

\subsection{Chemicals}

6-hydroxy-2,5,7,8-tetramethylchroman carboxylic acid (Trolox). Xanthine oxidase (XOD) and 2,2'-Azino-bis(3-ethylbenzothiazoline-6-sulfonic acid) diammonium salt (ABTS) were obtained from Wako (Osaka, Japan). The mutagen 2- aminoanthracene (2-AA) was purchased from Acros Organics (New Jersey, USA), hydrogen peroxide (H2O2) and Methylmethanesulfonate (MMS) were purchased from Sigma-Aldrich (PO. St Louis, USA). Histidine, biotine and Agar-Agar from Difco (Paris, France). Aroclor 1254 was purchased from Supelco (USA).

\subsection{Plant materials}

A. salicina was collected from the Arid Region Institute (IRA) situated in the south east of Tunisia in October, 2003. Botanical identification was carried out by Pr. M. Chaib [15] (Department of Botany, Faculty of Sciences of Sfax). A voucher specimen (AS-10.03) has been kept in the Laboratory of Pharmacognosy, Faculty of Pharmacy of Monastir for future reference. The leaves were shade-dried, powdered, and stored in a tightly closed container.

\subsection{Extraction procedure and preliminary phytochemical analysis}

One hundred twenty grams of powder, from dried leaves, were sequentially extracted in a Soxhlet apparatus (6 h) (AM Glassware, Aberdeen, Scotland, United Kingdom) with petroleum ether, chloroform and ethyl acetate. We obtained the correspondent extracts for each solvant. These types of extracts, with different polarities, were concentrated to dryness and the residues were kept at $4^{\circ} \mathrm{C}$. Then, each extract was resuspended in the adequate solvant.

Plant materials were screened for the presence of tannins, flavonoids, coumarins and sterols using the methods previously described by Boubaker et al. [16].

The polyphenol content of $A$. salicina leave extracts was quantified by the Folin-Ciocalteau reagent as described by Yuan et al. [17]. The Gallic acid (0.2 mg/ $\mathrm{mL}$ ) was used as a standard.
The polyphenol content was expressed according to the following formula:

$\%$ Polyphenols $=([$ DO extract $\times 0.2) /$ DO Gallic acid $] /$ Extract concentration $\times 100$

However, flavonoid content was determined according to the modified method of Zhishen et al. [18]. The Quercetin $(0.05 \mathrm{mg} / \mathrm{mL})$ was used as a standard compound. The flavonoïd content was expressed according to the following formula:

$\%$ Flavonoids $=([$ DO extract $\times 0.05) /$ DO Quercetin $] /$ Extract concentration $\times 100$

The total sterol content was evaluated as described by Skandrani et al. [19]. The sterol content was expressed according to the following formula:

$$
\% \text { Sterols }=\left(\mathrm{P}_{\text {steroids }} / \mathrm{P}_{\text {extract }}\right) \times 100
$$

$$
\text { Where } \mathrm{P}_{\text {steroids }}=(\mathrm{Mf}-\mathrm{MO}) \times 0.25
$$

MO: Weight filter (mg), Mf: Weight of filter and precipitate (mg).

The method described by Pearson [20], was used for the determination of tannin content of samples which is evaluated according to the following formula:

$\%$ Tannins $=($ DO extract $/ \varepsilon \times 1) /$ Extract concentration $\times 100$

where $\varepsilon$; molar extinction coefficient $(=1 \mathrm{~g}-1 \mathrm{~cm}-1)$ of tannic acid (= 3.27 L g-1 cm-1).

\subsection{Radical-scavenging activity on $\mathrm{ABTS}^{+\cdot}$}

An improved ABTS radical cation decolorization assay was used. It involves the direct production of the blue/ green ABTS+. chromophore through the reaction between ABTS and potassium persulfate. Addition of antioxidants to the preformed radical cation reduces it to ABTS, to an extent and on a timescale depending on the antioxidant activity, the concentration of the antioxidant and the duration of the reaction. ABTS was dissolved in water to a $7 \mathrm{mM}$ concentration. $\mathrm{ABTS}^{+}$. was produced by reacting ABTS stock solution with 2.45 $\mathrm{mM}$ potassium persulfate (final concentration) and allowing the mixture to stand in the dark at room temperature for 12-16 h before use. The $\mathrm{ABTS}^{+}$. solution was diluted with ethanol to an absorbance of 0.7 ( \pm 0.02 ) at $734 \mathrm{~nm}$. In order to measure the antioxidant activity of extracts, $10 \mu \mathrm{l}$ of each sample at various concentrations $(0.5,2.5,4.5,7.5$ and $9.5 \mathrm{mg} / \mathrm{ml})$ was added to $990 \mu \mathrm{l}$ of diluted $\mathrm{ABTS}^{+\bullet}$ and the absorbance was recorded every $1 \mathrm{~min}$. We stop the kinetic reaction after $30 \mathrm{~min}$. Each concentration was analysed in triplicate. The percentage decrease of absorbance at $734 \mathrm{~nm}$ was calculated for each point and the antioxidant capacity of the test compounds was expressed as percent inhibition 
(\%). Trolox (6-hydroxy-2,5,7,8-tetramethylchroman- 2carboxylic acid) is used as a standard in comparison for the determination of the antioxidant activity of a compound. The results are also reported as the Trolox equivalent antioxidant capacity (TEAC), which is the molar concentration of the Trolox giving the same percentage decrease of absorbance of the ABTS as $1 \mathrm{mg} / \mathrm{ml}$ of the antioxidant testing extract, at a specific time point [21].

\subsection{DNA strand scission assay}

DNA damage and DNA protecting activity of extracts were detected on pBluescript KS DNA vector. Plasmid DNA was amplified and extracted from E.coli $\mathrm{DH} 5 \alpha$ then oxidized with $\mathrm{H}_{2} \mathrm{O}_{2}+\mathrm{UV}$ treatment in the presence or absence of the tested extracts and checked on $0.7 \%$ agarose in 1X TAE buffer (2 M Tris, $1 \mathrm{M}$ Sodium Acetate, $50 \mathrm{mM}$ EDTA, $\mathrm{pH}=8$ ) according to the method described by Russo et al. [22] with some modifications. In brief, the experiments were performed in a volume of $9 \mu \mathrm{l}$ in an Eppendorf tube containing 2.34 $\mu \mathrm{g}$ of plasmid DNA, $\mathrm{H}_{2} \mathrm{O}_{2}$ was added to a final concentration of 147 $\mathrm{mM}$ with and without $4 \mu \mathrm{l}$ of extracts at various concentrations.

The reaction was initiated by UV irradiation and continued for $5 \mathrm{~min}$ on the surface of UV transilluminator (Bioblock Scientific, TF35 C, France) with intensity of $180 \mathrm{~W}$, at $254 \mathrm{~nm}$ under room temperature. After irradiation, the mixture was incubated at room temperature during $15 \mathrm{~min}$. Finally, the reaction mixture along with gel loading dye was placed on $0.7 \%$ agarose gel for electrophoresis. Untreated pKS DNA was used as a control in each run of gel electrophoresis. Gel was stained with ethidium bromide and photographed with Bio-print (Vilbert lourmat, France).

\subsection{Bacterial strains}

Salmonella typhimurium strains TA102 and TA104 which are histidine-requiring mutants, were kindly provided by Pr.I. Felzen, (Universidade do Estado do Rio de Janeiro [UERJ], Rio de Janeiro, Brazil), and maintained as described by Maron and Ames [23]. The genotypes of the test strains were checked routinely for their histidine requirement, deep rough $(r f a)$ character, UV sensitivity (uvrB mutation) and presence of the $\mathrm{R}$ factor. They were stored at $-80^{\circ} \mathrm{C}$. S. typhimurium TA104 and TA102 strains are known to be more responsive to certain mutagens as (2-AA) and (MMS) [23,24].

Strains TA102 and TA104 contain AT base pairs at the hisG428 mutant site. The mutation is carried on the multi-copy plasmid pAQ1 in strain TA102 and on the chromosome in strain TA104. The plasmid confers tetracycline resistance, which is a convenient marker to detect the presence of the plasmid. The hisG428 mutation is an ochre mutation, TAA, in the hisG gene which can be reverted by all six possible base-pair changes; both transitions and transversions. This mutation is also reverted by mutagens that cause oxidative damage [25].

\subsection{9 preparation}

The S9 microsome fraction is prepared from livers of rats treated with Aroclor 1254 [23]. The components of S9 mix were $8 \mathrm{mM} \mathrm{MgCl}_{2}, 32.5 \mathrm{mM} \mathrm{KCl,} 5 \mathrm{mM}$ G6P, 4 mM NADP, $0.1 \mathrm{M}$ sodium phosphate buffer $(\mathrm{pH}=7.4)$, and S9 fraction at a concentration of $0.68 \mathrm{mg} / \mathrm{ml}$ of mix. The S9 mix was prepared freshly for each assay.

\subsection{Salmonella-microsome assay}

One hundred microliters of an overnight culture of bacteria (cultivated for $16 \mathrm{~h}$ at $37^{\circ} \mathrm{C}$, approximate cell density $\left.(2-5) \times 10^{8} \mathrm{cells} / \mathrm{ml}\right)$ and $500 \mu \mathrm{l}$ of sodium phosphate buffer $(0.2 \mathrm{M}, \mathrm{pH} 7.4$ for assay without S9) or $500 \mu \mathrm{l}$ of S9 mix were added to $2 \mathrm{ml}$ aliquots of top Agar (supplemented with $0.5 \mathrm{mM}$ L-histidine and 0.5 $\mathrm{mM}$ D-biotine) containing different concentrations of each extract. The resulting complete mixture was poured on minimal agar plates prepared as described by Maron and Ames [23]. The plates were incubated at $37^{\circ}$ $\mathrm{C}$ for $48 \mathrm{~h}$ and the revertant bacterial colonies of each plate were counted. Negative and positive control cultures gave numbers of revertants per plate that were within the normal limits found in the laboratory. An extract was considered mutagenic if the number of revertants per plate was at least doubled in S.typhimurium TA104 and TA 102 strains over the spontaneous revertant frequency $[23,26]$. Data were collected with a mean \pm standard deviation of three plates $(n=3)$.

\subsection{Antimutagenicity testing}

A modified plate incorporation procedure [27] was employed to determine the effect of all isolates on 2amino anthracene (2-AA) and Methylmethane sulfonate (MMS) induced mutagenicity. In brief, $0.5 \mathrm{ml}$ of $\mathrm{S} 9 \mathrm{mix}-$ ture for indirect mutagen (2-AA) and $0.5 \mathrm{ml}$ of phosphate buffer for direct mutagen MMS was distributed in sterilized capped tubes in an ice bath, then $0.1 \mathrm{ml}$ of test compounds and/or $50 \mu \mathrm{l}$ of mutagen and $100 \mu \mathrm{l}$ of test compound and $0.1 \mathrm{ml}$ of bacterial culture (prepared as described in mutagenicity test) were added. After vortexing gently and preincubating at $45^{\circ} \mathrm{C}$ for $30 \mathrm{~min}, 2 \mathrm{ml}$ of top agar supplemented with $0.05 \mathrm{M}$ L-histidine and D-biotine were added to each tube and vortexed for $3 \mathrm{~s}$. The resulting, entire was overlaid on the minimal agar plate. The plates were incubated at $37^{\circ} \mathrm{C}$ for $48 \mathrm{~h}$ and the revertant bacterial colonies on each plate were counted. The inhibition rate of mutagenicity (\%) was calculated relative to those in the control group with the 
mutagen by the following formula: percent inhibition $(\%)=[1-(($ number of revertants on test plates - number of spontaneous revertants)/(number of revertants on positive control plates - number of spontaneous revertants)) $] \times 100$.

Each dose was tested in triplicate.

\subsection{Statistical analyses}

Data are expressed as mean \pm standard deviation from three replicates. The statistical analyses were performed with STATISTICA edition 99 France. Duncan test was used to compare tested compounds vs. positive control. Difference was considered significant when $\mathrm{P}<0.05$.

\section{Results}

\subsection{Phytochemical study}

The results of our assay on the tested extracts are shown in Table 1. The EA extract showed the presence of significant quantities of tannins, flavonoids and polyphenols. Chl extract showed the presence of coumarins. Whereas, the sterols are detected in a very high quantity in the PE and Chl extracts.

\subsection{Determination of Total Polyphenol, Flavonoid, tannins and sterols Contents}

The phytochemical study of $A$. salicina extracts showed the presence of various quantities of polyphenols, sterols, tannins and flavonoids (Table 2). The significant content of polyphenols was recorded in EA and Chl extracts. In fact the percentage of total polyphenolic compounds content EA and Chl extracts were 3.31 and $3.62 \%$ respectivly. The EP extract showed the presence of an important quantity of sterols $12.5 \%$. The percentage of tannin and flavonoid content in EA extract, were respectively $1.9 \%$ and $2.2 \%$.

\subsection{ABTS-scavenging activity}

The antioxidant activity of a given compound depends not only on its chemical structure but also on the type of the generated radical it can neutralize. For this reason, we tested the antioxidant potential of the A. salicina extracts against more than one radical type. The

Table 1 Phytochemical screening of extracts from Accacia salicina

\begin{tabular}{cccc}
\hline & PE extract & Chl extract & EA extract \\
\hline Sterols & ++++ & ++ & - \\
Flavonoids & - & - & +++ \\
Tanins & - & - & +++ \\
Coumarins & - & ++ & ++ \\
polyphenols & - & ++ & ++ \\
Yield $(\%)$ & 1.90 & 3.24 & 2.31 \\
\hline
\end{tabular}

- = not detectable; $+=$ low quantitiy $++=$ average quantitiy $+++=$ high quantitiy $++++=$ very high quantitiy
Table 2 Quantitative phytochemical screening of extracts from Accacia salicina leaves

\begin{tabular}{llll}
\hline Extract content (\%) & PE extract & Chl extract & EA extract \\
\hline Tanins(\%) & - & - & $1.9 \pm 0.01$ \\
Flavonoid(\%) & - & - & $2.2 \pm 0.01$ \\
Polyphenols (\%) & - & $3.62 \pm 0.008$ & $3.31 \pm 012$ \\
sterols(\%) & $12.5 \pm 0.02$ & $5 \pm 0.007$ & $2 \pm 0.01$ \\
\hline
\end{tabular}

(results are represented by the means \pm SD of three experiments)

antioxidant activity measurements of the $A$. salicina extracts, against ABTS $^{{ }^{+}}$, was expressed as Trolox equivalent antioxidant capacity (TEAC). Since TEAC is a quantification of the effective antioxidant activity of the extract, a higher TEAC would translate a greater antioxidant activity of the tested sample.

The results obtained are summarized in Table 3. EA and $\mathrm{Chl}$ extracts exhibited a high antioxidant potential with TEAC values of and $0.81 \pm 0.0070 .95 \pm 0.004$ $\mathrm{mM}$, respectively. EP extract antioxidant capacity were less potent with TEAC values of $0.24 \pm 0.008 \mathrm{mM}$.

\subsection{Effect of Accacia salicina extracts on pKS plasmid DNA scission induced by hydroxyl radicals}

In order to evaluate the ability of the extracts to generate breaks in the phosphodiester bands of DNA, or unlike to protect DNA against the effect of hydroxyl radicals generated by the photolysis of hydrogen peroxide exposed to UV light, plasmid DNA was treated with different concentrations of each extract.

DNA derived from pKS plasmid showed two bands on agarose gel electrophoresis (lane A) the faster moving prominent band which corresponded to the native supercoiled circular DNA and the slower moving band was the open circular form. The UV irradiation of DNA in the presence of $\mathrm{H}_{2} \mathrm{O}_{2}$ resulting the cleavage of native supercoiled circular DNA to give prominent open circular form and a faint linear DNA indicating that $\mathrm{OH}^{\text {. }}$ generated from UV-photolysis of $\mathrm{H}_{2} \mathrm{O}_{2}$ produced DNA strand scission.

The results showed that the treatment with all extracts doses, did not result in changes in plasmid DNA conformation. These observations suggest that if the extracts cause DNA damage, it is not through direct DNA chain breakage.

In the same way, protective effect of the extracts against $\mathrm{OH}^{-}$induced DNA cleavage, was also studied (Figure 1). All extracts effectively inhibited $\mathrm{OH}^{\cdot}$ induced DNA cleavage at the all tested doses.

\subsection{Mutagenic activity of extracts}

No one of the tested extracts induced significant increase of the revertant number of S. typhimurium TA102 and S. typhimurium TA104 strains, as well with 
Table 3 TEAC of ABTS radical formation by Acaccia salicina leaf extracts

\begin{tabular}{|c|c|c|c|c|}
\hline Extracts $^{b}$ & $\begin{array}{l}\text { Concentrations } \\
(\mathrm{mg} / \mathrm{mL})\end{array}$ & Inhibition percentage ${ }^{a}(\%)$ & $\begin{array}{l}\mathrm{I} C_{50} \\
(\mathrm{mg} / \mathrm{mL})\end{array}$ & TEAC values $\mathrm{mM}$ \\
\hline & 0.05 & $1.86 \pm 1.11$ & & \\
\hline \multirow[t]{5}{*}{ PE extract } & 0.5 & $10.5 \pm 2.23$ & & \\
\hline & 2.5 & $16.7 \pm 2.36$ & - & $0.24 \pm .008$ \\
\hline & 4.5 & $28 \pm 1.11$ & & \\
\hline & 7.5 & $41.5^{*} \pm 2.18$ & & \\
\hline & 0.05 & $2.52 \pm 2.03$ & & \\
\hline \multirow[t]{5}{*}{ Chl extract } & 0.5 & $19.2 \pm 2.53$ & $1.91 \pm 0.08$ & $\mathbf{0 . 8 1} \pm 0.007$ \\
\hline & 2.5 & $57.8^{*} \pm 2.81$ & & \\
\hline & 4.5 & $72.20^{*} \pm 3.82$ & & \\
\hline & 7.5 & $91^{*} \pm 1.65$ & & \\
\hline & 0.05 & $5.52 \pm 2.06$ & & \\
\hline \multirow[t]{4}{*}{ EA extract } & 0.5 & $28 \pm 1.68$ & & \\
\hline & 2.5 & $90.2^{*} \pm 2.12$ & $1.2 \pm 0.04$ & $\mathbf{0 . 9 5} \pm 0.004$ \\
\hline & 4.5 & $99.28^{*} \pm 1.92$ & & \\
\hline & 7.5 & 100 & & \\
\hline TRolox ${ }^{c}$ & & & $\mathbf{0 . 2 6 \pm 0 . 0 3}$ & 1 \\
\hline
\end{tabular}

as without metabolic activation (S9) (table 3). It was inferred that neither A.salicina extracts nor their metabolits exhibit a mutagenic effect.

\subsection{Antimutagenicity assay}

Doses of 5 and $10 \mu \mathrm{g} /$ plate of (2-AA), 325 and $130 \mu \mathrm{g} /$ plate of (MMS) were chosen for the antimutagenicity studies with respectively TA104 and TA102 strains. Since these doses were not toxic and induced $1149 \pm 15$ ( $5 \mu \mathrm{g} /$ plate of 2 -AA $)$, and $2144 \pm 23(325 \mu \mathrm{g} /$ plate of MMS) revertants in S. typhimurium TA104. (2-AA) at the concentration of $10 \mu \mathrm{g} /$ plate induced $652 \pm 10$ revertants and (MMS) at the concentration of $130 \mu \mathrm{g} /$ plate induced $1721 \pm 24$ revertants, in TA102 strain.
Table 4 showed that $\mathrm{Chl}$ extract was the most effective in reducing the mutagenicity caused by the direct mutagen MMS, in the TA 104 assay system with respectively inhibition percentages of $64.35 \%$ (at a dose of 25 $\mu \mathrm{g} /$ plate) and $55.07 \%$ (at a dose of $10 \mu \mathrm{g} /$ plate). The addition of Petroleum ether extract and Ethyl acetate extract decreased the mutagenicity caused by MMS with respectively $37.66 \%$ and $44.54 \%$ (at a dose of $25 \mu \mathrm{g}$ / plate). The inhibition percentage of Petroleum ether extract and Ethyl acetate extract decreased at the different other tested doses.

Chl extract showed the most important antimutagenic effect against MMS in the TA102 assay system, in a reverse dose dependent manner $(48.75 \%$ at a dose of 25

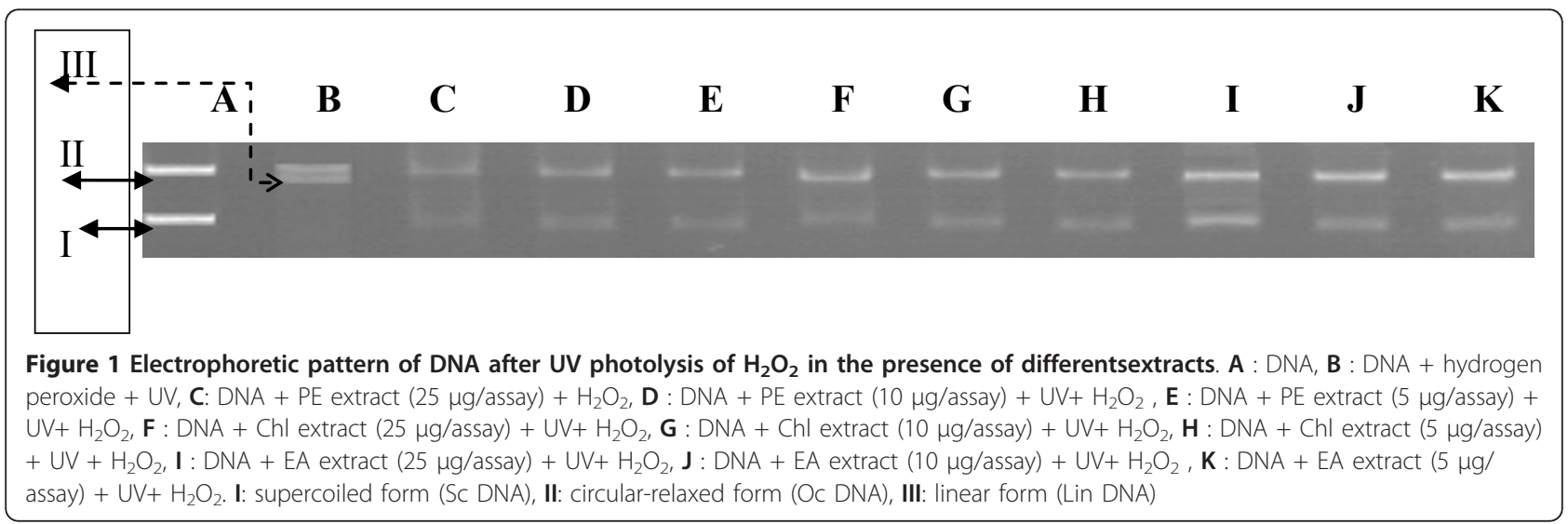


Table 4 Mutagenic effect of different Accacia salicina leaf extracts in S.typhimurium TA104 and TA102 assay systems in the presence and absence of an exogenous metabolic activation system (S9)

\begin{tabular}{|c|c|c|c|c|c|}
\hline \multirow[t]{2}{*}{ Extracts } & \multirow{2}{*}{$\begin{array}{l}\text { Doses } \\
\text { ( } \mu \mathrm{g} / \text { plate })\end{array}$} & \multicolumn{2}{|c|}{ TA 104} & \multicolumn{2}{|c|}{ TA 102} \\
\hline & & -59 & +S 9 & -59 & $+\mathrm{S9}$ \\
\hline Spontaneous & - & $312 \pm 8$ & $335 \pm 11$ & $244 \pm 18$ & $265 \pm 25$ \\
\hline PC & - & $2144 \pm 23$ & $1149 \pm 15$ & $1721 \pm 24$ & $652 \pm 10$ \\
\hline \multirow[t]{2}{*}{ Petroleum ether extract } & 25 & $352 \pm 21$ & $375 \pm 18$ & $289 \pm 11$ & $294 \pm 14$ \\
\hline & 10 & $348 \pm 14$ & $369 \pm 17$ & $260 \pm 14$ & $284 \pm 15$ \\
\hline \multirow[t]{3}{*}{ Chloroform extract } & 5 & $336 \pm 16$ & $361 \pm 19$ & $249 \pm 13$ & $270 \pm 17$ \\
\hline & 25 & $336 \pm 10$ & $359 \pm 21$ & $299 \pm 13$ & $304 \pm 12$ \\
\hline & 10 & $328 \pm 11$ & $353 \pm 13$ & $249 \pm 13$ & $289 \pm 15$ \\
\hline \multirow[t]{4}{*}{ Ethyl Acetate extract } & 5 & $318 \pm 10$ & $344 \pm 9$ & $242 \pm 15$ & $275 \pm 19$ \\
\hline & 25 & $381 \pm 15$ & $363 \pm 16$ & $254 \pm 22$ & $304 \pm 14$ \\
\hline & 10 & $333 \pm 17$ & $356 \pm 20$ & $246 \pm 12$ & $294 \pm 11$ \\
\hline & 5 & $322 \pm 25$ & $340 \pm 09$ & $242 \pm 18$ & $272 \pm 19$ \\
\hline
\end{tabular}

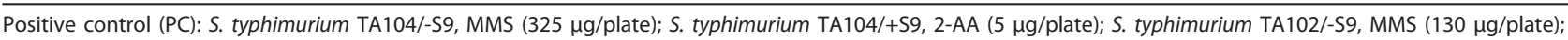
S. typhimurium TA102/+S9, 2 AA (10 $\mu \mathrm{g} /$ plate).

MMS: Methylmethane sulfonate, 2-AA: 2-amino anthracene

$\mu g /$ plate) (Table 5). Wheres EA and PE extracts exhibited a maximum inhibition of the (MMS) induced mutagenicity of respectively $41.15 \%$ and $32.41 \%$ at the tested dose of $25 \mu \mathrm{g} /$ assay.

Chl extracts were highly effective in reducing the mutagenicity caused by the indirect mutagen 2-AA, with $62.77 \%$ in the S. typhimurium TA104 assay system and $89 \%$ in the S. typhimurium TA102 assay system at a dose of $25 \mu \mathrm{g} /$ plate (table 6). EA extract was significant effective in reducing the mutagenicity caused by the indirect mutagen 2 -AA, with $37 \%$ in the S. typhimurium TA104 assay system and $42.2 \%$ in the S. typhimurium TA102 assay system at a dose of $25 \mu \mathrm{g} /$ plate. Whereas no antimutagenic significant effect is detect at the low tested doses in respectivrely the S. typhimurium TA102 and S. typhimurium TA104 assay systems.

$\mathrm{PE}$ extract was significant effective in reducing the mutagenicity caused by the indirect mutagen 2-AA, with $27.51 \%$ in the S. typhimurium TA104 assay system and $31.65 \%$ in the S. typhimurium TA102 assay system at a dose of $25 \mu \mathrm{g} /$ plate. Whereas no antimutagenic significant effect is detect at the low tested doses in respectivrely the S. typhimurium TA102 and S. typhimurium TA104 assay systems.

\section{Discussion}

Cellular mechanisms and external factors involved in the production of oxidative stress include the inflammatory

Table 5 Effect of different extracts from Accacia salicina leaves on the mutagenicity induced by MMS in Salmonella thyphimurium TA104 and TA102 assay systems without S9

\begin{tabular}{|c|c|c|c|c|c|}
\hline \multirow[b]{2}{*}{ Extracts } & \multirow[b]{2}{*}{$\begin{array}{l}\text { Doses } \\
\text { ( } \mu \mathrm{g} / \text { plate) }\end{array}$} & \multicolumn{2}{|r|}{ TA104 } & \multicolumn{2}{|r|}{ TA102 } \\
\hline & & $\mathrm{Nb}$ revertants & $\%$ inhibition of mutagenesis & $\mathrm{Nb}$ revertants & $\%$ inhibition mutagenesis \\
\hline Spontaneous & & $312 \pm 8$ & - & $234 \pm 18$ & - \\
\hline PC & & $2144 \pm 23$ & - & $1721 \pm 24$ & - \\
\hline \multirow[t]{3}{*}{ Petroleum ether extract } & 25 & $1454 \pm 95$ & 37.66 & $1239 \pm 73$ & 32.41 \\
\hline & 10 & $1712 \pm 45$ & 23.58 & $1265 \pm 42$ & 30.66 \\
\hline & 5 & $2002 \pm 43$ & 7.75 & $1325 \pm 56$ & 2.63 \\
\hline \multirow[t]{3}{*}{ Chloroform extract } & 25 & $965 \pm 99$ & 64.35 & $996 \pm 68$ & 48.75 \\
\hline & 10 & $1135 \pm 64$ & 55.07 & $1016 \pm 82$ & 47.41 \\
\hline & 5 & $1266 \pm 59$ & 47.92 & $1099 \pm 47$ & 41.82 \\
\hline \multirow[t]{3}{*}{ Ethyl acetate extract } & 25 & $1328 \pm 58$ & 44.54 & $1109 \pm 73$ & 41.15 \\
\hline & 10 & $1475 \pm 98$ & 36.51 & $1195 \pm 42$ & 35.37 \\
\hline & 5 & $1813 \pm 54$ & 18.06 & $1235 \pm 56$ & 32.68 \\
\hline
\end{tabular}

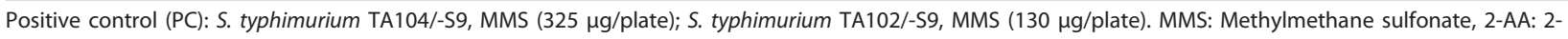
amino anthracene. 
Table 6 Effect of different extracts from Accacia salicina leaves on the mutagenicity induced by 2-AA in Salmonella thyphimurium TA104 and TA102 assay systems in the presence of S9

\begin{tabular}{|c|c|c|c|c|c|}
\hline \multirow[t]{2}{*}{ Extracts } & \multirow[b]{2}{*}{ Doses ( $\mu \mathrm{g} / \mathrm{plate})$} & \multicolumn{2}{|r|}{ TA104 } & \multirow{2}{*}{\multicolumn{2}{|c|}{$\begin{array}{lc} & \text { TA } 102 \\
\text { Nb revertants } & \% \text { inhibition of mutagenesis }\end{array}$}} \\
\hline & & $\mathrm{Nb}$ revertants & $\%$ inhibition of mutagenesis & & \\
\hline Spontaneous & & $335 \pm 11$ & - & $235 \pm 12$ & - \\
\hline$P C$ & & $1149 \pm 15$ & - & $652 \pm 10$ & - \\
\hline \multirow[t]{2}{*}{ Petroleum ether extract } & 25 & $925 \pm 46$ & 27.51 & $520 \pm 11$ & 31.65 \\
\hline & 10 & $934 \pm 14$ & 26.41 & $\begin{array}{l}582 \pm 8 \\
948 \pm 10\end{array}$ & 16.78 \\
\hline \multirow[t]{3}{*}{ Chloroform extract } & 5 & $1105 \pm 28$ & 5.4 & & - \\
\hline & 25 & $638 \pm 47$ & 62.77 & $281 \pm 16$ & 89 \\
\hline & 10 & $764 \pm 38$ & 47.3 & $426 \pm 17$ & 54.2 \\
\hline \multirow[t]{4}{*}{ Ethyl acetate extract } & 5 & $881 \pm 22$ & 32.9 & $506 \pm 7$ & 35 \\
\hline & 25 & $847 \pm 34$ & 37 & $476 \pm 5$ & 42.2 \\
\hline & 10 & $865 \pm 52$ & 34.88 & $584 \pm 17$ & 16.3 \\
\hline & 5 & $1077 \pm 19$ & 8.84 & $652 \pm 6$ & - \\
\hline
\end{tabular}

response, auto-oxidation of catecholamine, xanthine oxidase activation, pro-oxidants activities of toxins. Scavengers counteract the damaging effects of reactive oxygen species [28]. However, when the balance between these reactive species and antioxidants is altered, a state of oxidative stress results, possibly leading to permanent cellular damage.

Mutations are important early steps in carcinogenesis, therefore, a short term genetic test, such as the Salmonella/reversion assay and DNA strand scission assay, have been successfully used for the detection of mutagens/carcinogens, as well as of antimutagens/anticarcinogens [29]. The absence of mutagenicity for PE, Chl and EA extracts of Accaia salicina in the two Salmonella tested strains TA102 and TA104, with and without (S9) activation system, as well as the absence of phosphodiester band breaks in plasmid DNA at any tested concentration of the different extracts, indicate that DNA does not seem to be revelant target for these extracts [30,31].

In the present experiment we have first investigated the protective role of $A$. salicina extracts against the ABTS $^{+}$. EA extract revealed a best antiradical activity against ABTS radicals. This should be correlated to their chemical constituents as they are composed by polyphenols and flavonoids in EA extract against ABTS radical. This finding is supported by previous studies reported by Orhan et al. [32] who revealed that the sage polyphenols, including flavone glycosides, were found to display potent antioxidant activities free radicals. In the same context, Hirano et al. [33] and Engelmans et al. [34] demonstrated the flavonoids are able to directly capture the radical species, thus interrupting the radical step of propagation.

This highly activity exhibited by $\mathrm{Chl}$ and EA extracts may be correlated to another chemical content. The polyphenolic content appears to function as potent electron and hydrogen atom donors, and therefore should be able to terminate the radical chain reaction by converting the free radicals and the reactive oxygen species to more stable products. Similar observation about the polyphenolic constituents has been reported for several plant extracts such as tea $[35,36]$.

DNA strand scission induced by hydroxyl radicals. Hydroxyl radical is the most reactive radical known in chemistry. It can abstract hydrogen atoms from biological molecules, including thiols, leading to the formation of sulphur radicals capable to combine with oxygen to generate oxysulfur radicals, a number of which damage biological molecules [37]. Althought, both (O2 $\left.{ }^{--}\right)$and $\mathrm{H}_{2} \mathrm{O}_{2}$ are potentially cytotoxic, most of the oxidative damage in biological systems is caused by the $\mathrm{OH}^{*}$, which is generated by the reaction between $\left(\mathrm{O} 2^{--}\right)$and $\mathrm{H}_{2} \mathrm{O}_{2}$ in the presence of metal ions [38]. The UV irradiation of DNA in the presence of $\mathrm{H}_{2} \mathrm{O}_{2}$ resulting the cleavage of Sc DNA to give a prominent Oc DNA and a faint linear DNA indicated that $\mathrm{OH}$ generated from UV photolysis of $\mathrm{H}_{2} \mathrm{O}_{2}$ produced DNA strand scission. The tested extracts showed a significant inhibiting activity against hydroxyl radicals, with the different doses tested. Sterols which are the main constituents of PE and Chl extracts, and which are described as pocessing significant antioxidant activity $[39,40]$ are likely candidates for providing the antigenotoxic effect of these extracts. It is possible that these compounds inhibit the free radicals and ROS produced by oxidation and redox-cycling. We hypothesize that the sterols present in the PE extract, possess different antioxidant properties than those present in the Chl extract, and exhibited a weak scavenging effect than $\mathrm{Chl}$ extract against some free radicals. The molecules in the two extracts should have different polarities. These types of compounds; were reported, by 
many authors, to exhibit an inhibitory effect against some radical systems $[41,39,40,42]$.

In the other hand, the scavenging potential for hydroxyl radicals of Chl extract may be also correlated to its polyphenol content. In fact, polyphenols are an important group of pharmacologically active compounds. They are considered to be the most active antioxidant derivatives in plants $[43,44]$. However, it has been shown that the phenolic content does not necessary follow the antioxidant activity. Antioxidant activity is generally the result of the combined activity of a wide range of compounds, including phenolics, peptides, organic acids and other components [45].

The chemical components of EA extracts should be better scavenger free radicals. In fact both of them contain flavonoids which are described by Rice-Evans [46] and Kumar and Chattopadhyay [47], as effective hydrogen donors, making extracts potent antioxidants. These compounds should also act through a variety of mechanisms including scavenging of ROS [48]. We believe that the presence of such chemicals in the EA extract explain the important $\mathrm{O} 2-$ scavenging effect of both extracts. In a study employing a non-enzymatic system to generate superoxide radicals [49], it was shown that flavonoids are able to scavenge O2- [50].

As far as antioxidants has attracted much interest with respect to their protective effect against free radical damage that may be the cause of many diseases including cancer, antimutagenic activity of A. salicina extracts was investigated in the present study.

In the present experimental conditions $\mathrm{Chl}$ extract was an effective antimutagen against two different types of genotoxic compounds direct and indirect acting mutagenes suggesting that the extracts can act through various mechanisms. They reduced frameshift mutagenicity induced by (2-AA) and (MMS), an direct-indirect acting agent, suggesting that they could interfere with the metabolic activation of promutagens, by functioning as blocking agents [51]. The $P-450$ enzyme system catalyzes the formation of $N$-hydroxy derivatives, such as $N$ ydroxy-2- aminoanthracene (a metabolite that interacts with DNA). Thus, an alteration in the function of the enzyme may result in altered reaction rates and differential pathways of the metabolism of mutagens and carcinogens. In some cases, this modification provides protection against chemically induced mutagenesis. In fact, this effect is known to play a role in the antimutagenicity of some plant extracts $[51,52]$. These data agree with the knowledge that anticarcinogenicity of polyphenols contributes to block the formation of carcinogen [53]. However, the Chl extract may also directly protect DNA from the electrophilic metabolites of the mutagen given that favonoids provide strong nucleophilic centers, which enables them to react with electrophilic mutagens and form adducts that may result in the prevention of genotoxic damage [54]. The observed antimutagenicity of the Chl extract in the TA102 strain (sensitive to oxidative damage) and TA104 strain is congruent with its strong antioxidant capacity. This result suggests that consumption of the studied plants could be an alternative for reducing genotoxic damage induced by free radicals. The observed antioxidant potential could be related to the presence of polyphenolic compounds [55-57]. Polyphenols, which are widely distributed in the plant kingdom and are present in considerable amounts in fruits, vegetables, spices, medicinal herbs, and beverages, have been used to prevent many human diseases, such as diabetes, cancers, and coronary heart diseases [58]. The biological activities of polyphenols in different systems are believed to be due to their redox properties, which can play an important role in absorbing and neutralizing free radicals, quenching singlet and triplet oxygens, or decomposing peroxides [59].

Sterols, wich are the main constituents of PE extract, seem to be most likely candidates for providing the observed antimutagenic activity of this extract [41].

Protective effect of PE, Chl and EA extracts against the tested mutagens may probably adsorb the mutagen in a way similar to the carcinogen adsorption which has been associated with pyrrole pigments, such as hemin and chlorophyllin $[60,61]$.

The differents antimutagenic activity of Chl than EA and PE extracts could be explained by the antioxidant activity is often the result of the combined activity of a wide range of compounds, including phenolics, peptides, organic acids and other components [62] and to the different sensibilities of the two strains towards a given compound or complex [63].

\section{Conclusion}

In conclusion, the present study demonstrates that extracts of $A$. salicina possesses potent antioxidant and antimutagenic activities. These extract is capable of protecting against oxidative DNA damage. Further investigations on testing their in vivo activities and on isolation and characterization of the active compounds responsible for the antioxidant capacity of A. salicina leaf extracts are under way in our laboratory.

\section{Acknowledgements}

We acknowledge the "Ministère Tunisien de l'Enseignement Supèrieur, de la Recherche et de la Technologie "for the support of this study.

\section{Author details}

${ }^{1}$ Department of Cellular and Molecular Biology, Faculty of Dental Medicine, Rue Avicenne,Monastir, 5000, Tunisia. ${ }^{2}$ Department of Pharmacognosy, Faculty of Pharmacy, Rue Avicenne, Monastir, 5000, Tunisia. 


\section{Authors' contributions}

JB: Was responsible for the conception and design, testing and data acquisition, analysis and data interpretation and drafted the manuscript. HBM: Was responsible for the conception and design, testing and data acquisition, analysis and data interpretation and drafted the manuscript. The two first authors are contributed equally in this work

KG: made substantial contribution to conception and revised it critically for important intellectual content. LCG: made substantial contribution to conception and revised it critically for important intellectual content. All authors read and approved the final manuscript.

\section{Conflict of interests statement}

The authors declare that they have no competing interests.

Received: 20 September 2011 Accepted: 1 December 2011 Published: 1 December 2011

\section{References}

1. Bartolome A, Mandap K, David KJ, Sevilla F III, Villanueva J: SOS-red fluorescent protein (RFP) bioassay system for monitoring of antigenotoxic activity in plant extract. Biosens Bioelectron 2006, 21:2114-2120.

2. Fraga CG, Arias RF, Llessuy SF, Koch OR, Boveris A: Effect of vitamin E and seleniumdeficiency on rat liver chemiluminescence. Biochem J 1987, 2:383-386.

3. ramarathan N, OSAWA NT, Namiki M, Tashiro T: I SCI fOOD Agri 1986, 37:719.

4. Ben Sghair M, Boubaker J, Naffati Aicha, Limem I, Skandrani I, Bhouri W, Bouhlel I, Kilani S, Chekir Ghedira L, Ghedira K: Antimutagenic and Antioxidant Potentials of Teucrium Ramosissimum Essential Oil. Chem Biodiverity 2010, 7:1-10.

5. Johnson FB, Sinclair DA, Guarente L: Molecular biology of aging. Cell 1999, 2:291-302

6. Gulcin I, Bursal E, Sehitoglu MH, Bilsel M, Goren AC: Polyphenol contents and antioxidant activity of lyophilized aqueous extract of propolis from Erzurum, Turkey. Food and Chem Toxicol 2010, 48:2227-2238.

7. Wadood A, Wadood N, Wahid Shah SA: Effects of Acacia arabica and Caralluma edulis on blood glucose levels of normal and alloxan diabetic rabbits. J Pak Med Assoc 1989, 39:208-212.

8. Sotohy SA, Sayed AN, Ahmed MM: Effect of tannin-rich plant (Accacia nilotica) on some nutritional and bacteriological parameters in goats. Deutsche Tierarztliche Wochenschrift 1997, 104:432-435.

9. Dafallah AA, Al-Mustapha Z: Investigation of the anti-inflammatory activity of Acacia nilotica and Hibiscus sabdariffa. Am J Chinese Med 1996, 24:263-269.

10. Ghosh NK, Babu SP, Sukul NC, Ito A: Cestocidal activity of Acacia auriculiformis. J of Helmintol 1996, 70:171-172.

11. Amos S, Akah PA, Odukwe CJ, Gamaniel KS, Wambede C: The pharmacological effects of an aqueous extract from Acacia nilotica seeds. Phytother Res 1999, 13:683-685.

12. Gilani AH, Shaheen F, Zaman M, Janbaz KH, Shah BH, Akhtar MS: Studies on hypertensive and antispasmodic activities of methanol extract of Acacia nilotica pods. Phytother Res 1999, 14:510-516.

13. Shah BH, Safdar B, Virani SS, Nawaz Z, Saeed SA, Gilani AH: The antiplatelet aggregatory activity of Accacia nilotica is due to blockage of calcium influx through membrane calcium channels. General Pharmacol 1997, 29:251-255.

14. Hussein G, Miyashiro H, Nakamura N, Hattori M, Kakiuchi N, Shimotohno K: Inhibitory effects of Sudanese medicinale plant eextracts on hepatitis $C$ virus (HCV). Phytother Res 2000, 14:510-516.

15. Cheib M, Boukhris M: Flore succinct et illustré des zones arides et sahariennes de Tunisie. 1998, 49:43-44.

16. Boubaker J, Skandrani I, Bouhlel I, Ben Sghaier M, Neffati A, Ghedira K, Chekir-Ghedira L: Mutagenic, antimutagenic and antioxidant potency of leaf extracts from Nitraria retusa. Food and Chem Toxicol 2010, 48:2283-2290

17. Yuan W, Bone DE, Carrington F: Antioxidant activity of dulse (Palmaria palmata) extract evaluated in vitro. Food Chem 2005, 91:485-494.

18. Zhishen J, Mengcheng T, Jianming W: The determination of flavonoid contents in mulberry and their scavenging effects on superoxide radicals. Food Chem 1999, 64:555-559.
19. Skandrani I, Ben Sghaier M, Neffati A, Boubaker J, Bouhlel I, Kilani S, Mahmoud A, Ghedira K, Chekir-Ghedira L: Antigenotoxic and free radical scavenging activities of extracts from Moricandia arvensis. Drug Chem Toxicol 2007, 30:361-382.

20. Pearson D: The Chemical Analysis of Foods. London: Churchill Livingstone; 7 1976, 572

21. Gulcin I: Antioxidant properties of resveratrol: A structure-activity insight Innovative Food Science and Emerging Technologies 2010, 11:210-218.

22. Russo A, Acquaviva R, Campisi A, Srrenti V, Di Giacomo C, Virgata G: Bioflavonoids as antiradicals, antioxidants and DNA cleavage protectors. Cell Biol Toxicol 2000, 16:91-98.

23. Maron DM, Ames BN: Revised methods for the Salmonella mutagenicity test. Mutat Res 1983, 113:173-215.

24. Nelson GM, Swank AE, Brooks LR, Bailey KC, George SE: Metabolism, microflora effects, and genotoxicity in haloacetic acid-treated cultures of rat cecal microbiota. Toxicology Science 2001, 60:232-241.

25. Mortelmans K, Zeiger E: The Ames Salmonella/microsome mutagenicity assay. Mutat Resear 2000, 455:29-60.

26. Marques RCP, De Medeiros SRB, Da Silva Dias C, Barbosa-Filho JM, AgnezLima LF: Evaluation of the mutagenic potential of yangambin and of the hydroalcoholic extract of Ocotea duckei by the Ames test. Mutation Research 2003, 536:117-120.

27. Lee KT, Sohn IC, Park HJ, Kim DW, Jung GO, Park KY: Essential moiety of antimutagenic and cytotoxic activity of hederagenin monodesmosides and bidesmosides isolated from the stem bark of Kalapanox pictus. Planta Medica 2000, 66:329-332.

28. Uliasz TF, Hewett SJ: A microtiter trypan blue absorbance assay for the quantitative determination of excytotoxic neuronal injury in cell culture. Journal of Neuroscience Methods 2000, 100:157-163.

29. Rausher R, Edenharder R, Platt KL: In vitro antimutagenic and in vivo anticlastogenic effects of carotenoids and solvent extracts from fruits and vegetables rich in carotenoids. Mutation Research 1998, 413:129-142.

30. Kilani S, Ben Ammar R, Bouhlel I, Abdelwahed A, Hayder N, Mahmoud A, Ghedira K, Chekir-Ghedira L: Investigation of extracts from (Tunisian) Cyperus rotundus as antimutagens and radical scavengers. Environmental Toxicology and Pharmacology 2005, 3:478-484.

31. Ben Ammar R, Bouhlel I, Valenti K, Ben Sghaier M, Kilani S, Mariotte AM, Dijoux-Franca MG, Laporte F, Ghedira K, Chekir-Ghedira L: Transcriptional response of genes involved in cell defense system in human cells stressed by $\mathrm{H} 2 \mathrm{O} 2$ and pre-treated with (Tunisian) Rhamnus alaternus extracts: Combination with polyphenolic compounds and classic in vitro assays. Chemico-Biological Interactions 2007, 168:171-183.

32. Orhan I, Kartal M, Naz Q, Ejaz A, Yilmaz G, Kan Y, Konuklugil B, Sener B, Choudhary MI: Antioxidant and anticholinesterase evaluation of selected Turkish Salvia species. Food Chem 2007, 103:1247-1254.

33. Hirano R, Sasamoto W, Matsumoto A, Itakura H, Igarashi O, Kondo K: Antioxidant ability of various flavonoids against DPPH radicals and LDL oxidation. J Nutr Sci Vitaminol 2001, 47:357-362.

34. Engelmann MD, Hutcheson R, Cheng IF: Stability of Ferric Complexes with 3-Hydroxyflavone(Flavonol), 5,7-Dihydroxyflavone (Chrysin), and 3', 4'Dihydroxyflavone. J Agric Food Chem 2005, 53:2953-2960.

35. Yen GC, Chen HY: Antioxidant activity of various tea extracts in relation to their antimutagenicity. J Agric Food Chem 1995, 43:27-32.

36. Amorowicz R, Pegg RB, Rahimi-Moghaddam P, Barl B, Weil JA: Free radical scavenging capacity of selected plant species from the Canadian prairies. Food Chem 2004, 84:551-562.

37. Dahl MK, Richardson T: Photogeneration of superoxide anion in serum of bovine milk and in model systems containing riboflavin and amino acid. Journal of Dairy Science 1978, 61:400-407.

38. Halliwell B: Reactive oxygen species in living systems: source, biochemistry, and role in human disease. Annal Journal Medical 1991, 91:14-25.

39. Argolo ACC, Sant'Ana AEF, Pletsch M, Coelho LCBB: Antioxidant activity of leaf extracts from Bauhinia monandra. Bioresource Technology 2004, 95:229-233.

40. Ben Mansour H, Boubaker J, Bouhlel I, Mahmoud A, Bernillon S, Ben Chibani J, Ghedira K, Chekir-Ghedira L: Antigenotoxic activities of crude extracts from Acacia salicina leaves. Environmental and Molecular Mutagenesis 2007, 48:58-66.

41. Bouhlel I, Valenti K, Kilani S, Skandrani I, Ben Sghaier M, Mariotte AM, Dijoux-Franca MG, Ghedira K, Hininger-Favier I, Laporte F, Chekir-Ghedira L: 
Antimutagenic, antigenotoxic and antioxidant activities of Acacia salicina extracts (ASE) and odulation of cell gene expression by $\mathrm{H} 2 \mathrm{O} 2$ and ASE treatment. TIV 2008, 22:1264-1272.

42. Shon MY, Choi SD, Kahng GG, SH N, Sung NJ: Antimutagenic, antioxidant and free radical scavenging activity of ethyl acetate extracts from wite, yellow and red onions. Food Chemi Toxicol 2004, 42:659-666.

43. Edenharder R, Grunhage D: Free radical scavenging abilities of flavonoids as mechanism of protection against mutagenicity induced by tertbutyl hydroperoxide or cumene hydroperoxide in Salmonella typhimurium TA102. Mutation Research 2003, 540:1-18.

44. Park KY, Jung GO, Lee KT, Choi J, Choi MY, Kim GT, Jung HJ, Park HJ: Antimutagenic activity of flavonoids from the heartwood of Rhus verniciflua. J Ethnopharmacol 2004, 90:73-79.

45. Gallardo C, Jimenez L, Garcia-Conesa MT: Hydroxycinnamic acid composition and in vitro antioxidant activity of selected grain fractions. Food Chemi 2006, 99:455-463.

46. Rice-Evans CA, Miller NJ, Bramley PM, Pridham JB: The relative antioxidant activity of plant derived polyphenolic flavonoids. Free Rad Res 1995, 22:375-383.

47. Kumar A, Chattopadhyay S: DNA damage protecting activity and antioxidant potential of pudina extract. Food Chem 2006, 100:1377-1384.

48. Vundac VB, Brantner AH, Plazibat M: Content of polyphenolic constituents and antioxidant activity of some Stachys taxa. Food Chem 2007, 104:1277-1281.

49. Schuldta EZ, Farias MR, Ribeiro-do-Vallea RM, Ckless K: Comparative study of radical scavenger activities of crude extract and fractions from Cuphea carthagenensis leaves. Phytomed 2004, 11:523-529.

50. Shu-Jing $W u$, Lean-Teik Ng: Antioxidant and free radical scavenging activities of wild bitter melon (Momordica charantia Linn. var. abbreviata Ser.) in Taiwan. LWT Food Sci Technol 2008, 41:323-330.

51. Horn RC, Ferrao WM: Antimutagenic activity of extracts of natural substances in the Salmonella/microsome assay. Mutagenesis 2003, 18:113-118.

52. Zani F, Cuzzoni MT, Daglia M, Benvenuto S, Vampa G, Mazza P: Inhibition of mutagenicity in Salmonella typhimurium by Glycyrrhiza glabra extract, glycyrrhizinic acid,18 alpha-, and 18 beta-glycyrrhetinic acids. Planta Medica 1993, 59:502-507.

53. Lin JK, Liang YC: Cancer Chemoprevention by Tea Polyphenols Proceedings of the National Science Council. ROC(B) 24, No. 1. 2000, 1-13.

54. Marnewick LJ, Gelderblom CAW, Joubert E: An investigation on the antimutagenic properties of South African teas. Mutation Research 2000, 471:157-166.

55. Galati G, O'Brien JP: Potential toxicity of flavonoids and others dietary phenolics: significance for their chemopreventive and anticancer properties. Free Radical Biology and Medicine 2004, 37:287-283.

56. Okawa M, Kinjo J, Nohara T, Masateru O: DPPH (1,1-diphenyl-2picrylhydrazyl) radical scavenging activity of flavonoids obtained from some medicinal plants. Biological Pharmaceutical Bullettin 2001, 24:1202-1205.

57. Payet B, Sing CS, Smadia J: Assessment of antioxidant activity of cane sugars by ABTS and DPPH radical scavenging assays: determination of their polyphenolic and volatile constituents. Journal of Agricultural and Food Chemistry 2005, 53:10074-10079.

58. Broadhurst CL, Polansky MM, Anderson RA: Insulin-like activity of culinary and medicinal plant aqueous extracts in vitro. Journal of Agricultural and Food Chemistry 2000, 48:849-852.

59. Oswa T: Novel natural antioxidants for utilization in food and biological systems. In Post-harvest Biochemistry of Plant Food Materials in the Tropics. Edited by: Uritany I, Garcia W, Mendoza EM. Tokyo: Japan Scientific Society Press; 1994:241-251.

60. Ferguson RL, Philpott M, Karunasinghe N: Dietary cancer and prevention using antimutagens. Toxicology 2004, 198:147-159.

61. Ikuma NEM, Passoni HM, Biso IF, Longo CM, Cardoso PRC, Campaner SL, Varanda AE: Investigation of genotoxic and antigenotoxic activities of Melampodium divaricatum in Salmonella typhimurium. Toxicology In Vitro 2006, 20:361-366.

62. Vundac VB, Brantner AH, Plazibat M: Content of polyphenolic constituents and antioxidant activity of some Stachys taxa. Food Chem 2007, 104:1277-1281.
63. Skandrani I, Bouhlel I, Limem I, Boubaker J, Bhouri W, Neffati A, Ben Sghaier M, Kilani S, Ghedira K, Ghedira-Chekir L: Moricandia arvensis extracts protect against DNA damage, mutagenesis in bacteria system and scavenge the superoxide anion. Toxicology in Vitro 2009, 23:166-175.

doi:10.1186/1476-0711-10-37

Cite this article as: Boubaker et al:: Antimutagenic and free radical scavenger effects of leaf extracts from Accacia salicina. Annals of Clinical Microbiology and Antimicrobials 2011 10:37.

\section{Submit your next manuscript to BioMed Central and take full advantage of:}

- Convenient online submission

- Thorough peer review

- No space constraints or color figure charges

- Immediate publication on acceptance

- Inclusion in PubMed, CAS, Scopus and Google Scholar

- Research which is freely available for redistribution 